\title{
Ecumenical truthmaking: a précis of $A$ Theory of Truthmaking
}

\author{
Jamin Asay ${ }^{1}$ D
}

Received: 18 October 2021 / Accepted: 25 November 2021 / Published online: 13 January 2022

(c) The Author(s), under exclusive licence to Springer Nature B.V. 2022

\begin{abstract}
The theory of truthmaking has long aroused skepticism from philosophers who believe it to be tangled up in contentious ontological commitments and unnecessary theoretical baggage. I argue in A Theory of Truthmaking that this suspicion is unfounded. Philosophers across the spectrum can take advantage of truthmaking and use it to better understand the ontological implications of topics that arise all over the philosophical landscape. Challenging the current orthodoxy that truthmaking's fundamental purpose is to be a tool for explaining why truths are true, the book revives the conception of truthmaking as fundamentally an exercise in ontology: a means for coordinating one's beliefs about what is true and one's ontological commitments. I go on to show how truthmaking connects to analyticity, truth, and realism and how it contributes to debates over nominalism, presentism, mathematical objects, and fictional characters.
\end{abstract}

Keywords Truthmaking $\cdot$ Truth $\cdot$ Realism $\cdot$ Ontology $\cdot$ Explanation

You, too, can be a truthmaker theorist. Perhaps you already are. That ecumenical spirit is the driving force behind much of the argumentation in A Theory of Truthmaking. In its pages, I defend a conception of truthmaker theory that is not antecedently committed to a variety of substantive metaphysical commitments that might be too robust for philosophers with exacting metaphysical scruples. On my view, nominalists can be truthmaker theorists. So may anti-realists of various stripes. Deflationists about truth can-and should-join the truthmaking camp, for their view about "truth" applies perfectly well to the "truth" in "truthmaking."

By developing an ecumenical approach to truthmaking, and thereby lowering its bar to entry, I risk satisfying no one at all. Those who are happy to embrace the more substantial theoretical commitments about which I hesitate might find no advantage to my strategy. Those who are already skeptical of truthmaking may find

Jamin Asay

asay@hku.hk

1 Department of Philosophy, University of Hong Kong, Pokfulam, Hong Kong 
nothing to gain by taking it seriously. But it is to the latter group that I am primarily evangelizing. Truthmaking need not be the sole province of a specialist corner of metaphysics. It is, rather, a useful means for regimenting and pursuing ontological investigation.

Accordingly, I open the book by identifying truthmaking out in the "wild," where it might not be expected to appear. Consider Gettier's (1963) argument that justified true belief is insufficient for knowledge. In one of Gettier's scenarios, the justified true believer bases his belief on a state of affairs that is not the one in virtue of which the belief is true, and thus fails to know it. Hence, Gettier invokes an epistemic principle to the effect that knowledge requires the knower to base their belief on whatever in fact makes the belief true.

Or consider epistemicism about vagueness, which maintains that there is some $x$ such that "Possessing exactly $x$ dollars - and not a penny more or less-is minimally sufficient for being rich" is true. This position is frequently met with incredulity, and I believe that it has a metaphysical root. What could possibly make such a sentence true? Its truth needs to depend on something, but what would uniquely determine that value? Hence, what is driving this resistance to epistemicism is one's ontological scruples: such a sentence can't be true because nothing exists to make it true.

These examples illustrate the idea that truth depends on being. Sentences about the pocket contents of a future employee are made true by the contents of that future employee's pockets, not someone else's. If there is a fact of the matter about exactly where the line between the rich and the poor is, it must be due to something in reality. Discussions of truthmaking frequently begin by heralding the slogan that truth depends on reality - it doesn't "hang on air," as Armstrong puts it (2004: 3). I, too, trumpet the slogan that truth depends on reality-it's the first sentence of the book. But my main purpose in the monograph is not to defend the slogan but to put it to work. I argue that we can use truthmaking to develop better accounts of philosophically important phenomena like truth, analyticity, and realism. And then I argue that we can use truthmaking to probe a variety of ongoing metaphysical debates.

Before I apply my truthmaking framework, however, I develop it by defending what I believe to be the best answers to several fundamental questions about truthmaking. Three are the most important. First, is truthmaking fundamentally an exercise in ontology or explanation? Second, what is the truthmaking relation? Finally, do all truths have truthmakers?

These questions are intertwined, so to answer them it's crucial to consider why we should care about truthmaking in the first place. My strategy is to identify two separate perspectives on the goal of truthmaking, both of which can be gleaned from the literature. The first-what I call ontological accounting - takes truthmaking to be an exercise in ontology, a means for determining what exists. Those interested in truthmaking are wary of theories that rely on certain truths while not giving those truths sufficient ontological attention. Consider Crispin Wright's account of moral truth: moral judgments are true when they are superassertible, and they are superassertible when they possess warrant that would survive any kind of enhancement to our information (1992: 48). Crucially, he offers this account as an alternative to moral realism. But notice that Wright has the truth of moral judgments depend on the truth of a particular sort of counterfactual. And what makes those 
counterfactuals true? These facts about the sustainability of warrant don't "hang on air." Without an account of the ontology responsible for such counterfactuals, we lack a basis for properly classifying the account as anti-realist. After all, it could be that the best answer to what makes those counterfactuals true is precisely the ontology offered by the moral realist.

For the ontological accountant, the goal of truthmaker theory is to provide a comprehensive ontological account of the world, an answer to the question of what there is. They are guided in this endeavor by considering what there needs to be in the world to make true all we take to be true. The second approach to truthmaker theory takes it to be a project of alethic explanation. Truthmaker inquiries answer the question of why truths are true. The explanation-first theorist should agree with the accountant that truthmaker theory will furnish the correct ontological inventory. But they go further by claiming that there is a specific explanatory debt incurred by (at least some) truths, such that we haven't explained them until we've offered an ontology that explains why they are true. For example, suppose one gives detailed explanations for why Chris Patten was the final governor of Hong Kong by relying on historical accounts of his appointment and details of the Hong Kong political system both before and after its handover to China. Nevertheless, one still hasn't (fully) addressed the question of why "Chris Patten was the final governor of Hong Kong" is true until one offers a truthmaker for it.

I adopt the ontological accounting view of truthmaking. The explanatory approach is vulnerable to difficult objections, bears the burden of articulating the specific explanatory project that can only be addressed by truthmakers, and too closely resembles substantive theories of truth (like correspondence theories). The accounting approach also enables me to offer a straightforward answer to my second question, concerning the truthmaking relation. The major issue here is whether or not metaphysical necessitation is necessary and sufficient for truthmaking. An object necessitates the truth of a truth-bearer if and only if it's metaphysically necessary that if the object exists, the truth-bearer is true. The orthodox position today is that necessitation is necessary but not sufficient for truthmaking. I agree with and argue for the former claim. I disagree with the latter, arguing that necessitation is both necessary and sufficient for truthmaking.

The most familiar argument against the sufficiency of necessitation involves necessary truths. It's metaphysically necessary that if my copy of Plato's Complete Works exists, "13 is prime" is true. Trivially, every object necessitates every necessary truth. But, goes the objection, each and every existing object does not make every necessary truth true: "13 is prime" is not true in virtue of my Platonic tome. Therefore there must be some hyperintensional component to truthmaking, such that it is more discriminating a relation than purely modal necessitation.

I argue against these purported counterexamples by showing how the project of ontological accounting is in no way disrupted by allowing a more liberal account of truthmaking. (My view that mathematical truths are analytic is relevant here as well.) We can still explain these truths straightforwardly: it's true that 13 is prime because it is larger than 1 and has no factors besides 1 and itself. This is not a "truthmaking explanation," but it remains to be seen what a truthmaking explanation is, and why it is required. Those concerned with alethic explanation should 
defend the principle of sufficient reason. Those concerned with ontology should defend truthmaking.

Finally there is the question of whether all truths have truthmakers (maximalism) or only a proper subset (non-maximalism). If one took truth itself to be explained in terms of truthmaking, maximalism is required. Non-maximalism is, however, available to the ontological accountant, and independently attractive. The most salient candidate truthmaker gaps (i.e., truths without truthmakers) are negative existentials. It's true that there are no mermaids, but it's not obvious that there is something whose very existence guarantees that no mermaid exists. Thus, I defend the view that the way to properly ontologically account for the truth of negative existentials is to exclude certain entities (i.e., mermaids) from one's ontology, not to include some other type of entity (such as a "mermaid absence"). Not all ontological accounting is ontological addition.

After considering these basic questions about truthmaking, what emerges is a spectrum. On one end, there is a theorist like myself who takes truthmaking to be in the business of ontological accountability, favors a purely modal truthmaking relation, embraces truthmaker gaps, has a fairly deflationary attitude toward necessary truth, and distances themselves from a substantive account of the property of truth. On the other side is someone who takes truthmakers to offer a distinctive form of alethic explanation, and pairs that with a hyperintensional account of the truthmaking relation, maximalism, a very non-trivial perspective on necessary truth, and a substantive theory of truth (perhaps like a classical correspondence account). I do hope that the book's arguments encourage those on the other side of the spectrum to reconsider their views. But remember my ecumenical ambitions: my greater hope is that those who reject truthmaking altogether will reappraise it once they see the availability of my end.

Even those who defend a more committed account of truthmaking can follow me to the later portions of the book where I put truthmaker theory to work. In the middle section, I defend three main theses. First, though theories of truth and theories of truthmaking can and should be separated as distinct philosophical enterprises, adopting truthmaking ought to lead you to reject correspondence theories of truth, since truthmaker theory pulls the motivational rug out from under them. Second, analytic truths require nothing more than trivial truthmakers, and perhaps no truthmakers at all if truthmaking is in fact hyperintensional. In fact, this lack of substantive ontological grounding is a way of identifying analyticity itself. Third, much of what goes on in debates about realism (such as moral realism and scientific realism) can be understood in terms of truthmaking: the core metaphysical debates between realists and anti-realists are, at bottom, debates about truthmakers.

In the third and final section of the book I turn to core topics in metaphysics, and what emerges is something of a mixed bag. With respect to the problem of universals, I attempt to offer a truthmaking defense of a strong form of nominalism, but ultimately abandon it and align myself with a modest form of either realism or nominalism. I also defend eternalism. So I take on some more substantive metaphysical views and reject their more austere alternatives. But then I advocate highly deflationary accounts of mathematical and fictional entities. 
By no means do I believe that my truthmaking arguments settle any of these centuries-old metaphysical disputes. I agree with Armstrong that there is no "royal road" in metaphysics, and truthmaking is no exception (2004: 4). What I do think is that approaching these debates from the perspective of truthmaker theory has led to progress in the form of a collectively better understanding of what is at stake in these issues. Proper ontological accounting is a cognitive goal we should all strive to achieve, and I offer truthmaker theory to everyone as a means of realizing it.

Acknowledgements My thanks go to Nikolaj Pedersen for commissioning this symposium and to each of my critics for their valuable contributions.

Funding The research presented here was partially supported by a grant from the Research Grants Council of the Hong Kong Special Administrative Region, China (project number HKU 17618420), and funding from the University of Hong Kong's Outstanding Young Researcher Award.

\section{Declarations}

Conflict of interest The author declares no competing interests.

\section{References}

Armstrong, D. M. (2004). Truth and truthmakers. Cambridge University Press. Gettier, E. L. (1963). Is justified true belief knowledge? Analysis, 23, 121-123. Wright, C. (1992). Truth and objectivity. Harvard University Press. 